\title{
Nocturnal enuresis in sickle cell haemoglobinopathies
}

\author{
D R J Readett, J S Morris, G R Serjeant
}

\begin{abstract}
The prevalence of nocturnal enuresis (wet at least two nights a week) was investigated in children, aged 8, who were being followed up as part of a prospective cohort study. There were 175 children with homozygous sickle cell disease, 106 with sickle cell haemoglobin C disease, and 150 controls with a normal haemoglobin genotype. In homozygous sickle cell disease, 48 boys (52\%) and 31 girls (38\%) were enuretic, a significantly higher prevalence than in those with sickle cell haemoglobin $\mathrm{C}$ disease-five boys (10\%) and 11 girls $(20 \%)-o r$ in normal children-16 boys $(22 \%)$ and 13 girls (17\%). There was no significant difference between children with sickle cell haemoglobin $C$ disease and the normal genotype. Boys with homozygous sickle cell disease were significantly more likely to be enuretic if they came from large families; there was a similar trend for girls with homozygous sickle cell disease, although it did not reach significance. Enuresis was more common in boys with homozygous sickle cell disease who had low concentrations of fetal haemoglobin and in girls with sickle cell haemoglobin $\mathrm{C}$ disease who had high mean corpuscular haemoglobin concentrations. Similar associations were not shown for girls with homozygous sickle cell disease or boys with sickle cell haemoglobin $\mathrm{C}$ disease.
\end{abstract}

Nocturnal enuresis is a common problem in general paediatric practice. The reported prevalence varies because of differences in definition, but appears to be influenced by racial or cultural factors. ${ }^{1-4}$ Enuresis is acknowledged to be more common in children with homozygous sickle cell disease, although the reported studies have been small and usually lacked appropriate controls. ${ }^{5-7}$ The Jamaican cohort study of sickle cell disease has allowed the accurate documentation of enuresis in patients and controls and an assessment of associated haematological, clinical, and social risk factors.

\section{Patients and methods}

The study population consisted of the Jamaican children enrolled in a cohort study of sickle cell disease set up by the Medical Research Council Laboratories at the University of the West Indies. Neonatal cord blood screening of 100000 consecutive normal deliveries identified all infants with major haemoglobinopathies, born at the public maternity hospital in Kingston from July 1973 to December $1981 .^{8}$ There were 314 children with homozygous sickle cell disease and 201 with sickle cell haemoglobin $\mathrm{C}$ disease. The first 125 cases with homozygous sickle cell disease were each matched with two children of the same age and sex but with a normal haemoglobin genotype, giving 250 normal controls.

Children have been reviewed regularly: at intervals of three months and at any time between when they have been ill when there have been inquiries about nocturnal enuresis. At age 8 years ( \pm 6 months) each child was reviewed in detail and the presence or absence of enuresis noted along with other clinical, social, and anthropometric data. The present study is based on information obtained from both of these sources. For the purposes of the study enuresis was defined as being wet, regularly, at least two nights a week but for certain analyses an expanded definition of wet at least one night a month was also used.

The haematological indices examined in patients with and without enuresis were the mean of all steady state observations between 5 and 8 years of age. Routine haematological indices were measured by an electronic particle counter (Coulter ZB1 6 or Coulter S plus 4). Fetal haemoglobin was measured by the alkali denaturation method of Betke et al, ${ }^{9}$ and the diagnosis of homozygous sickle cell disease or sickle cell haemoglobin $\mathrm{C}$ disease was on standard criteria. ${ }^{10}$

Prevalence rates for enuresis are quoted with $95 \%$ confidence intervals and differences between genotypes were assessed by $\chi^{2}$ tests. Associations between enuresis and haematological indices were investigated by Student's $t$ test; fetal haemoglobin concentrations and reticulocyte counts required logarithmic transformation before analysis to normalise skewed distributions. $\chi^{2}$ tests for association and trend were used to examine the relationship between enuresis and social factors and multiple logistic regression analysis was then used to re-examine the relative contributions of family size and position in the family as these are interdependent variables. The Mann-Whitney nonparametric test was used to investigate the association of enuresis and disease severity, the latter being assessed by the total number of sick visits to clinic in the first eight years of life.

\section{Results}

The number of children, by sex and genotype, for whom reliable data were available is shown in table 1, which also shows the total number of children for whom data should have been available and hence the percentage ascertainment within each group. The discrepancy between 
Table 1 Sex, genotype, and ascertainment of cohort study children

\begin{tabular}{|c|c|c|c|c|c|c|c|c|c|}
\hline & \multicolumn{3}{|c|}{ Homozygous sickle cell disease } & \multicolumn{3}{|c|}{ Sickle cell haemoglobin $C$ disease } & \multicolumn{2}{|c|}{ Normal genotype } & \multirow[b]{2}{*}{ Total } \\
\hline & Boys & Girls & Total & Boys & Girls & Total & Boys & Girls & \\
\hline $\begin{array}{l}\text { Total possible sample size } \\
\text { No with reliable data } \\
\text { Ascertainment (\%) }\end{array}$ & $\begin{array}{r}109 \\
93 \\
85\end{array}$ & $\begin{array}{r}102 \\
82 \\
80\end{array}$ & $\begin{array}{r}211 \\
175 \\
83\end{array}$ & $\begin{array}{l}67 \\
51 \\
76\end{array}$ & $\begin{array}{l}65 \\
55 \\
85\end{array}$ & $\begin{array}{r}132 \\
106 \\
80\end{array}$ & $\begin{array}{l}88 \\
74 \\
84\end{array}$ & $\begin{array}{r}102 \\
76 \\
75\end{array}$ & $\begin{array}{r}190 \\
150 \\
80\end{array}$ \\
\hline
\end{tabular}

Table 2 Prevalence of enuresis at age 8 years

\begin{tabular}{|c|c|c|c|c|c|c|c|c|}
\hline & \multicolumn{4}{|l|}{ Boys } & \multicolumn{4}{|l|}{ Girls } \\
\hline & $\begin{array}{l}\text { Total } \\
\text { No }\end{array}$ & $\begin{array}{l}\text { No (\%) wet } \\
\geqslant 2 \\
\text { nights/ } \\
\text { week }\end{array}$ & $\begin{array}{l}95 \% \text { Confidence } \\
\text { interval }\end{array}$ & $\begin{array}{l}\text { No (\%) wet } \\
\geqslant 1 \\
\text { night/ } \\
\text { month }\end{array}$ & $\begin{array}{l}\text { Total } \\
\text { No }\end{array}$ & $\begin{array}{l}\text { No }(\%) \text { wet } \\
\geqslant 2 \\
\text { nights/ } \\
\text { week }\end{array}$ & $\begin{array}{l}95 \% \text { Confidence } \\
\text { interval }\end{array}$ & $\begin{array}{l}\text { No }(\%) \text { wet } \\
\geqslant 1 \\
\text { night/ } \\
\text { month }\end{array}$ \\
\hline $\begin{array}{l}\text { Homozygous sickle cell } \\
\text { disease }\end{array}$ & 93 & $48(52)$ & $42-62$ & $54(58)$ & 82 & $31(38)$ & $27-48$ & $42(51)$ \\
\hline $\begin{array}{l}\text { Sickle cell haemoglobin } \\
\text { C disease } \\
\text { Normal genotype }\end{array}$ & $\begin{array}{l}51 \\
74\end{array}$ & $\begin{array}{r}5(10) \\
16(22)\end{array}$ & $\begin{array}{r}2-18 \\
13-31\end{array}$ & $\begin{array}{l}13(25) \\
21(28)\end{array}$ & $\begin{array}{l}55 \\
76\end{array}$ & $\begin{array}{l}11(20) \\
13(17)\end{array}$ & $\begin{array}{l}9-31 \\
9-25\end{array}$ & $\begin{array}{l}22(40) \\
18(24)\end{array}$ \\
\hline
\end{tabular}

Table 3 Comparison of prevalence of enuresis (wet $\geqslant 2$ nights/week) between genotypes

\begin{tabular}{|c|c|c|c|}
\hline & \multicolumn{3}{|c|}{ Genotypes compared } \\
\hline & $\begin{array}{l}\text { Homozygous } \\
\text { sickle cell } \\
\text { disease } v \\
\text { normal }\end{array}$ & $\begin{array}{l}\text { Homozygous } \\
\text { sickle cell disease } \\
v \text { sickle cell } \\
\text { haemoglobin } C \\
\text { disease }\end{array}$ & $\begin{array}{l}\text { Sickle cell } \\
\text { haemoglobin } C \\
\text { disease } \\
v \text { normal }\end{array}$ \\
\hline $\begin{array}{l}\text { Boys } \\
\text { Girls } \\
\text { Both }\end{array}$ & $\begin{array}{r}<0.001 \\
0.003 \\
<0.001\end{array}$ & $\begin{array}{c}<0.001 \\
0.04 \\
<0.001\end{array}$ & $\begin{array}{l}0.130 \\
0.690 \\
0.560\end{array}$ \\
\hline
\end{tabular}

Figures indicate significance of $\chi^{2}$ test (p).

the total available study population and the number of children originally enrolled in the cohort study is accounted for by those children who died, those who emigrated or were lost to follow up, and those who had not yet reached 8 years of age at the time of the study. The age distribution of children within each genotype at the time of the eight year review was comparable with a mean (range) for homozygous sickle cell disease of $8 \cdot 0(7 \cdot 5-8 \cdot 5)$, sickle cell haemoglobin $C$ disease of $8 \cdot 1(7 \cdot 9-8 \cdot 5)$, and normal genotype $8 \cdot 1(7 \cdot 5-8 \cdot 5)$.

Prevalence rates for enuresis by genotype and sex are shown in table 2. Children with homozygous sickle cell disease were significantly more likely to be enuretic than either those with sickle cell haemoglobin $\mathrm{C}$ disease or those with a normal genotype $(p<0.001)$, there being no statistical difference between the latter two genotypes (table 3 ). None of the differences between the sexes reached significance.

\section{SOCIAL FACTORS}

When data for boys and girls were analysed together, children with homozygous sickle cell disease were significantly more likely to be enuretic if they came from larger families $(p=0.003$, table 4$)$ but children from single and dual parent families had similar rates of enuresis. Later position in the family was significantly associated with enuresis for children with homozygous sickle cell disease $(p=0.005$, table 4) but multiple logistic regression analysis showed that this could be largely accounted for by the effect of family size. The data in table 4 are compiled defining enuresis as wet at least two nights a week, although the same associations with family size $(p=0.001)$ and position in family $(p=0.03)$ are true for the expanded definition of wet at least once a month. Again the association with position within the family could be accounted for by the effect of family size.

When analysed separately by sex, there was a significant positive association for boys with homozygous sickle cell disease between family size and enuresis defined either as wet at least two nights a week $(p=0.002)$ or wet at least one night a month $(p=0.008)$, but there was no association between enuresis and position in the family. For girls with homozygous sickle cell disease there was a trend, which did not reach significance, for enuresis to be more common in children from larger families when defined as wet at least twice a week but no association was seen with position in the family. For the expanded definition of wet at least once a month, enuresis was significantly more common both with increasing family size $(p=0.02)$ and with later position in the family $(p=0.03)$. Multiple logistic regression analysis showed these associations to be interdependent, neither one reaching significance when corrected for the effect of the other. No association was found between enuresis and three assess-

Table 4 Effect of family size and position in family on prevalence of enuresis among children with homozygous sickle cell disease

\begin{tabular}{|c|c|c|c|c|c|c|c|c|c|c|}
\hline & \multicolumn{5}{|c|}{ No of children } & \multicolumn{5}{|c|}{ Position in family } \\
\hline & 1 & 2 & 3 & 4 & $5+$ & $1 s t$ & $2 n d$ & $3 r d$ & $4 t h$ & $5 t h+$ \\
\hline \multirow[t]{2}{*}{$\begin{array}{l}\text { Total No subjects } \\
\text { No (\%) enuretic }\end{array}$} & $\begin{array}{l}18 \\
4\end{array}(22)$ & $\begin{array}{l}31 \\
9\end{array}$ & $\begin{array}{l}39 \\
20(51)\end{array}$ & $\begin{array}{l}34 \\
18(53)\end{array}$ & $\begin{array}{l}38 \\
22(58)\end{array}$ & $\begin{array}{l}54 \\
18(33)\end{array}$ & $\begin{array}{l}36 \\
17(47)\end{array}$ & $\begin{array}{l}25 \\
17(68)\end{array}$ & $\begin{array}{r}23 \\
9\end{array}$ & $\begin{array}{l}22 \\
12(54)\end{array}$ \\
\hline & \multicolumn{5}{|c|}{$\begin{array}{l}p=0.03: \chi^{2} \text { test for association } \\
p=0.003: \chi^{2} \text { test for trend }\end{array}$} & \multicolumn{5}{|c|}{$\begin{array}{l}\mathrm{p}=0.05: \chi^{2} \text { test for association } \\
\mathrm{p}=0.005: \chi^{2} \text { test for trend }\end{array}$} \\
\hline
\end{tabular}


Table 5 Association of enuresis (wet $\geqslant 2$ nights/week) with steady state haematological indices for children with homozygous sickle cell disease

\begin{tabular}{|c|c|c|c|c|}
\hline Variable & Mean $(S D)$ enuretic & Mean $(S D)$ non-enuretic & $t$ & p Value \\
\hline $\begin{array}{l}\text { Haemoglobin }(g / l) \\
\text { Fetal haemoglobin* } \\
\text { Mean corpuscular haemoglobin concentration }(g / l) \\
\text { Reticulocytes* }\end{array}$ & $\begin{array}{l}76 \cdot 0(9 \cdot 3) \\
0 \cdot 79(0 \cdot 28) 5 \cdot 2 \% \dagger \\
342(26) \\
1 \cdot 07(0 \cdot 12) \quad 10 \cdot 7 \% \dagger\end{array}$ & $\begin{array}{l}79 \cdot 0(10 \cdot 6) \\
0 \cdot 91(0 \cdot 28) 7 \cdot 1 \% \dagger \\
343(16) \\
1.07(0 \cdot 12) 10 \cdot 7 \% \dagger\end{array}$ & $\begin{array}{l}-1 \cdot 60 \\
-2 \cdot 03 \\
-0 \cdot 34 \\
+0 \cdot 15\end{array}$ & $\begin{array}{l}0 \cdot 1 \\
0 \cdot 05 \\
0 \cdot 7 \\
0 \cdot 9\end{array}$ \\
\hline $\begin{array}{l}\text { Haemoglobin }(\mathrm{g} / \mathrm{l}) \\
\text { Fetal haemoglobin* } \\
\text { Mean corpuscular haemoglobin concentration }(\mathrm{g} / \mathrm{l}) \\
\text { Reticulocytes* }\end{array}$ & $\begin{array}{l}82.0(10.3) \\
0.87(0.22) 6.4 \% \dagger \\
345(16) \\
1.09(0.11) \quad 11.3 \% \dagger\end{array}$ & $\begin{array}{l}80 \cdot 0(10 \cdot 5) \\
0.87(0 \cdot 28) 6.4 \% \dagger \\
344(17) \\
1.07(0.13) \quad 10 \cdot 7 \% \dagger\end{array}$ & $\begin{array}{l}+0 \cdot 92 \\
+0 \cdot 14 \\
+0 \cdot 24 \\
+0 \cdot 84\end{array}$ & $\begin{array}{l}0 \cdot 4 \\
0 \cdot 9 \\
0 \cdot 8 \\
0 \cdot 4\end{array}$ \\
\hline
\end{tabular}

${ }^{*}$ Indices expressed transformed by $\log _{10}$ (variable +1$)$.

†Denotes means expressed in original units.

Table 6 Association of enuresis (wet $\geqslant 2$ nights/week) with steady state haematological indices for children with sickle cell haemoglobin $C$ disease

\begin{tabular}{|c|c|c|c|c|}
\hline Variable & Mean $(S D)$ enuretic & Mean (SD) non-enuretic & $t$ & $\overline{p \text { Value }}$ \\
\hline $\begin{array}{l}\text { Haemoglobin }(\mathrm{g} / \mathrm{l}) \\
\text { Fetal haemoglobin* } \\
\text { Mean corpuscular haemoglobin concentration }(\mathrm{g} / \mathrm{l}) \\
\text { Reticulocytes* }\end{array}$ & $\begin{array}{l}106 \cdot 0(5 \cdot 9) \\
0.30(0 \cdot 06) 2 \cdot 0 \% \dagger \\
356(15) \\
0.65(0 \cdot 12) 3.5 \% \dagger\end{array}$ & $\begin{array}{ll}s & \\
104 \cdot 0(7 \cdot 9) & \\
0.36(0 \cdot 17) & 2 \cdot 3 \% \dagger \\
355(13) & \\
0.70(0.14) & 4.0 \% \dagger\end{array}$ & $\begin{array}{l}+0 \cdot 46 \\
-0 \cdot 77 \\
+0 \cdot 24 \\
-0 \cdot 68\end{array}$ & $\begin{array}{l}0 \cdot 6 \\
0 \cdot 4 \\
0 \cdot 8 \\
0 \cdot 5\end{array}$ \\
\hline $\begin{array}{l}\text { Haemoglobin }(\mathrm{g} / \mathrm{l}) \\
\text { Fetal haemoglobin* } \\
\text { Mean corpuscular haemoglobin concentration }(\mathrm{g} / \mathrm{l}) \\
\text { Reticulocytes* }\end{array}$ & $\begin{array}{l}112 \cdot 0(8 \cdot 0) \\
0 \cdot 45(0 \cdot 19) 2 \cdot 8 \% \dagger \\
363(8) \\
0 \cdot 76(0 \cdot 21) 4 \cdot 7 \% \dagger\end{array}$ & $\begin{array}{l}s \\
108 \cdot 0(7 \cdot 7) \\
0 \cdot 48(0 \cdot 22) 3.0 \% \dagger \\
353(13) \\
0.69(0 \cdot 14) 3.9 \% \dagger\end{array}$ & $\begin{array}{l}+1 \cdot 60 \\
-0 \cdot 40 \\
+2 \cdot 38 \\
+1 \cdot 33\end{array}$ & $\begin{array}{l}0 \cdot 2 \\
0 \cdot 7 \\
0 \cdot 02 \\
0 \cdot 2\end{array}$ \\
\hline
\end{tabular}

${ }^{*}$ Indices expressed transformed by $\log _{10}$ (variable +1 ).

†Denotes means expressed in original units.

ments of socioeconomic status: the provision of running water inside the home or in the 'yard'; the presence of a flush, rather than a 'pit' toilet, and the provision of mains electricity in the home. Moreover there was no significant difference between the prevalence of enuresis for those children from families with all of the amenities and those with none.

For children with sickle cell haemoglobin C disease there were no trends or significant associations between enuresis and any of the social factors. For children of normal genotype the only significant finding was that girls were more likely to be enuretic if the family had a 'pit' rather than a flush toilet $(p=0.02$, for enuresis defined as wet at least twice a week). It should be noted, however, that for both of these genotypes the number of enuretic children in the analyses was small and this may have contributed to the lack of significant trends or associations.

\section{HAEMATOLOGICAL FACTORS}

Children with homozygous sickle cell disease (table 5)

When data for boys and girls were analysed together there were no significant associations but concentrations of haemoglobin $\mathrm{A}_{2}$ tended to be higher in the enuretic than the non-enuretic group $(p=0.05)$. When analysed separately enuretic boys tended to have lower concentrations of fetal haemoglobin than non-enuretics $(p=0.05)$ but for girls the concentrations were similar for the two groups. No other associations or consistent trends were demonstrated.

Children with sickle cell haemoglobin $C$ disease (table 6)

For boys and girls analysed together, mean corpuscular haemoglobin concentration tended to be higher in the enuretic than the nonenuretic group $(p=0.05)$. When analysed separately enuretic girls had significantly higher values for mean corpuscular haemoglobin concentration $(p=0.02)$ than non-enuretic but for boys the values were comparable for the two groups.

There was no association with $\alpha$ thalassaemia status for either genotype.

\section{DISEASE SEVERITY}

The number of visits for illness to the clinic in the first eight years of life, used as a measure of disease severity, was significantly greater for enuretic than non-enuretic boys with homozygous sickle cell disease $(p=0.03)$ but for girls a greater number was found in the non-enuretic than the enuretic group, although the difference did not reach significance.

\section{Discussion}

The present study confirms the previously suggested association between homozygous sickle cell disease and nocturnal enuresis, the prevalence at age 8 years being at least twice that found in control subjects of normal haemoglobin genotype. A similar association could not be shown for sickle cell haemoglobin $\mathrm{C}$ disease, prevalence in this genotype being similar to that in controls. The data do not, unfortunately, allow accurate differentiation of primary and secondary enuresis, but it is our impression that most children with homozygous sickle cell disease, who were still wet at 8 years of age, had primary enuresis.

Previous studies have suggested that the higher prevalence of enuresis in children with homozygous sickle cell disease is due to their 
poor urinary concentrating ability, ${ }^{4}$ which results from sickling within and destruction of the vasa recti countercurrent system of the renal medulla. ${ }^{11}$ This is thought to produce larger diurnal and nocturnal urinary volumes and hence delayed attainment of nocturnal urinary continence. The present study casts doubt on the simplicity of this hypothesis. If this were the only factor responsible for the higher prevalence of enuresis in children with homozygous sickle cell disease then one might expect a clear association between enuresis and haematological or clinical indices thought to reflect disease severity. Moreover, a higher prevalence of enuresis might have been expected in children with sickle cell haemoglobin $\mathrm{C}$ disease in whom medullary vascular damage also occurs. ${ }^{11}$

The present study has shown a weak association between enuresis and low concentrations of fetal haemoglobin for boys with homozygous sickle cell disease and a stronger association between enuresis and high mean corpuscular haemoglobin concentration values for girls with sickle cell haemoglobin $\mathrm{C}$ disease. Both of these haematological indices might be expected to enhance sickling within the renal medullary vasculature and produce more severe damage. The significance of these findings is difficult to assess, however, given the absence of similar associations in girls with homozygous sickle cell disease and boys with sickle cell haemoglobin $\mathrm{C}$ disease and the failure to show a higher prevalence of enuresis in girls with sickle cell haemoglobin $\mathrm{C}$ disease than in normal controls. It is also difficult to interpret the finding that enuresis was associated with a greater number of visits because of illness to the clinic and possibly, therefore, a more severe clinical course for boys with homozygous sickle cell disease when the opposite was found for girls with homozygous sickle cell disease.

Our results, therefore, have not excluded an effect of renal meduallary damage and high urinary volumes in the aetiology of enuresis in sickle cell disease but suggest that additional factors must be involved.

Enuresis in children with homozygous sickle cell disease showed, for boys, a significant positive association and, for girls, a clear trend with increasing family size in the present study. This has been reported previously for normal children, convincingly in a recent ${ }^{2}$ and less convincingly in an older $^{12}$ cohort study from Britain. Other workers have reported similiar trends that did not reach significance. ${ }^{13} 14$ This suggests that factors contributing to enuresis in normal children are also important in children with homozygous sickle cell disease. The lack of association between enuresis and the three measures of socioeconomic status in the present study might seem contradictory as most previous studies have shown at least a trend, ${ }^{14}$ and usually a significant association, 21213 between lower social class and enuresis. This can probably be explained by the social homogeneity of the cohort children's families, however, and the relative unreliability of social amenities in predicting social status in Jamaica, as a family in the country without running water or electricity may have a better standard of living than a family in Kingston who have both. The aetiological factors for enuresis in normal children and those with homozygous sickle cell disease, therefore, are probably similiar but factors specific to the homozygous sickle cell genotype must contribute to the prevalence, which is more than twice as high as in the normal children. The present study has not enabled these to be identified and further research will be needed to clarify the situation.

It is interesting that the prevalence of nocturnal enuresis in the controls with normal genotype was high compared with previously published normal population data. It is higher than that reported for Afro-American children in Baltimore, ${ }^{3}$ who themselves were more likely to be enuretic at 8 years than their white counterparts. These data, however, were not corrected for socioeconomic status, which is generally thought to influence the prevalence of enuresis in normal children. More recently, enuresis has been reported to be more common among Afro-Caribbean than white children in Britain and this association was shown to be independent of social class. ${ }^{2}$ Normal population data are not available for Jamaican children but preliminary results of a survey in Jamaican basic schools suggest that the controls of normal genotype in the cohort study are representative of the general population (DRJ Readett, unpublished observations).

In summary, this study has shown a definite association between nocturnal enuresis and homozygous sickle cell disease in children in Jamaica and has accurately documented the prevalence at 8 years of age. It has not provided an explanation for this association but has questioned the simplicity of existing theories and highlighted the need for further study.

1 de Jonge GA. Epidemiology of enuresis: a survey of the literature. In: Kolvin I, Mac Keith RC, Meadow SR, eds. Bladder control and enuresis. London: Heinemann, 1973. $39-46$

2 Golding J, Tissier G. Soiling and wetting. In: Butler NR Golding J, eds. From birth to five. Oxford: Pergamon Press, 1986:64-79.

3 Oppel WC, Harper PA, Rider RV. The age of attaining bladder control. Pediatrics 1986;42:614-26.

4 Crawford JD. Introductory comments. $\mathcal{f}$ Pediatr 1989 114(suppl):687-9.

5 Suster G, Oski FA. Enuresis in sickle cell anemia. Am $\mathcal{f}$ Dis Child 1967;113:311.

6 Noll JB, Newman AJ, Gross S. Enuresis and nocturia in sickle cell disease. F Pediatr 1967;70:965-7.

$7 \mathrm{Kwak}$ KJ, Scott RB, Ferguson AD. Studies in sickle cell anemia XXXIV. Observations on enuresis in children and nocturia in adults. Clin Pediatr (Phila) 1969;8:344-6.

8 Serjeant BE, Forbes M, Williams LL, Serjeant GR. Screening cord bloods for detection of sickle cell disease in Jamaica. Clin Chem 1974;20:666-9.

9 Betke K, Marti HR, Schlicht I. Estimation of small percentages of fetal haemoglobin. Nature 1959;184:1877-8. 10 Serjeant GR. Sickle cell disease. Oxford: Oxford University Press, 1985:37-47.

11 Statius van Eps LW, Pinedo-Veels C, de Vries GH De Koning J. Nature of concentrating defect in sickle cell nephrop

12 Miller FJW. Children who wet the bed. In: Kolvin I Mac Keith RC, Meadow SR, eds. Bladder control and Mac Keith RC, Meadow SR, eds. Bladder
enuresis. London: Heinemann, 1973:47-52.

13 Blomfield JM, Douglas JWB. Bedwetting - prevalence among children aged 4-7 years. Lancet 1956;i:850-2.

14 Rutter M, Yule W, Graham P. Enuresis and behavioural deviance: Some epidemiological considerations. In: Kolvin I, Mac Keith RC, Meadow SR, eds. Bladder contro and enuresis. London: Heinemann, 1973:137-47. 